\title{
Betel Leaf: The Neglected Green Gold of India
}

\author{
P. Guha \\ Agricultural and Food Engineering Department, Indian Institute of Technology, \\ Kharagpur, West Bengal, India \\ E-mail:pguha@agfe.iitkgp.ernet.in
}

KEYWORDS Agronomy. Anticarcinogen. Betel Leaf. Boroj. Essential Oil. Folk Medicine. Export

\begin{abstract}
The fresh leaves of betel vine are popularly known as Paan in India, which are consumed by about 15-20 million people in the country. It is cultivated following the traditional methods in India on about 55,000 ha with an annual production worth about Rs 9000 million. On an average about $66 \%$ of such production is contributed by the state of West Bengal where it is cultivated on about 20,000 ha encompassing about 4-5 lakh Boroj employing about the same number of agricultural families. There is a menacing wastage of the leaves during storage, transportation and the glut season. Moreover, the surplus leaves, if not disposed off properly may cause environmental pollution and health hazards. Such wastage may be minimized by various ways and means including extraction of essential oil from the surplus betel leaves. This oil may be used as an industrial raw material for manufacturing medicines, perfumes, mouth fresheners, tonics, food additives etc. The leaves are nutritive and contain anticarcinogens showing promise for manufacturing of a blood cancer drug. Some disputed reports also claim that chewing betel leaves excessively may cause oral cancer. The agricultural, industrial, economic, medicinal and allied potentialities of the crop are discussed.
\end{abstract}

\section{INTRODUCTION}

The deep green heart shaped leaves of betel vine are popularly known as Paan in India. It is also known as Nagaballi, Nagurvel, Saptaseera, Sompatra, Tamalapaku, Tambul, Tambuli, Vaksha Patra, Vettilai, Voojangalata etc in different parts of the country (CSIR, 1969; Guha and Jain, 1997). The scientific name of betel vine is Piper betle L. It belongs to the family Piperaceae, i.e. the Black Pepper family (Gunther, 1952). The vine is a dioecious (male and female plants are different), shade loving perennial root climber. There are about 100 varieties of betel vine in the world, of which about 40 are found in India and 30 in West Bengal (Guha, 1997; Maity, 1989; Samanta, 1994). The most probable place of origin of betel vine is Malaysia (Chattopadhyay and Maity, 1967). In spite of its alienness, the plant is much more popular in India than in any other country of the world since the antiquity. This would be evident from the numerous citations laid down in the ancient literature, particularly the Indian scriptures. In these citations, significance of the leaves has been explained in relation to every sphere of human life including social, cultural, religious and even day-to-day life, which is very much relevant even these days. For example, a well-prepared betel quid is still regarded as an excellent mouth freshener and mild vitalizer, routinely served on the social, cultural and religious occasions like marriage, Puja (religious festivals), Sraddha ceremony (religious function performed after cremation) etc. It is also used as a special item offered to the guests in order to show respect and for such traditional use of betel leaf in the Indian society, the leaf really stands alone without any parallel even today (Guha, 1997; Mehrotra, 1981). In fact, this edible leaf has achieved an esteemed position in the human society right from the dawn of civilization, particularly in the countries like Bangladesh, Burma, China, India, Indonesia, Malaysia, Nepal, Pakistan, Philippines, South Africa, Sri Lanka, Thailand etc. (Jana, 1996; Khoshoo, 1981; Samanta, 1994; Sharma et al., 1996), where leaves are traditionally used for chewing in their natural raw condition along with many other ingredients like sliced areca nut, slaked lime, coriander, aniseed, clove, cardamom, sweetener, coconut scrapings, ashes of diamond, pearl, gold and silver (Ayurvedic preparations), jelly, pepper mint, flavouring agent, fruit pulp etc. (CSIR, 1969).

\section{AGRONOMY AND AGRO-ECONOMICS OF BETEL LEAF PRODUCTION}

The betel vines (usually the male plants) are cultivated throughout India except the dry northwestern parts. Further, the female plants also rarely produce any flower or fruit in the Indian climate (CSIR, 1969). In spite of that the vines are cultivated for harvesting the heart shaped green leaves. It grows best under the shaded, tropical forest ecological conditions with a 
rainfall of about $2250-4750 \mathrm{~mm}$, relative humidity and temperature ranging from $40-80 \%$ and $15-40^{\circ} \mathrm{C}$, respectively. A well-drained fertile sandy or sandy loam or sandy clay soil with $\mathrm{pH}$ range of $5.6-8.2$ is considered suitable for its cultivation (CSIR, 1969; Guha and Jain, 1997). However, in the areas with lower rainfall (1500$1700 \mathrm{~mm}$ ) the crop is cultivated with small and frequent irrigations, i.e. every day in summer and every 3-4 days in winter, whereas adequate drainage is required during the rainy season (Jana, 1995; Mishra et al., 1997).

The vine is raised by vegetative propagation from the cuttings under partially shaded and humid environment inside the Boroj, which is a small hut like structure of approximately $2 \mathrm{~m}$ in height and 0.02 ha in area. It is constructed with the locally available materials like bamboo stems, jute sticks, paddy straw, petioles and leaves of banana etc. wherein the vines are grown on elevated beds imitating the natural ecological conditions suitable to the crop. However, height of the beds goes on increasing due to frequent earthing of the vines. Further, the cuttings from 3-5 years old vines are planted in the furrows (8$10 \mathrm{~cm}$ deep) of sterilized soil with spacing of 50$60 \mathrm{~cm} \mathrm{X} \mathrm{10-20} \mathrm{cm} \mathrm{during} \mathrm{rainy} \mathrm{or} \mathrm{autumn} \mathrm{season.}$ The vine is a highly labour intensive crop and a voracious feeder of nutrients requiring about $400-$ $600 \mathrm{Kg} \mathrm{N} / \mathrm{ha}, 200-300 \mathrm{Kg} \mathrm{P}_{2} \mathrm{O}_{5} / \mathrm{ha}$ and 200-250 $\mathrm{Kg} \mathrm{K}_{2} \mathrm{O} / \mathrm{ha}$, which are supplied only through the organic sources, normally the oil cakes, but in some places chemical fertilizer like urea is also being used sparingly now a days (Bhowmick, 1997; Guha and Jain, 1997; Jana, 1995; Jana, 1998; Maity, 1989). On the contrary, plantprotection-chemicals are used in a larger scale because the crop is very susceptible to insect pests and diseases, particularly the latter ones. In fact, the crop requires special care for its cultivation like sterilization of soil, which is achieved mainly by solarization (Jana, 1996). Further, fungicides like Bordeaux mixture $(0.5-1.0 \%)$ and Bavistin $(0.1 \%)$ and the insecticides like Malathion $(0.05 \%)$ and Endosulphan $(0.05 \%)$ are extensively sprayed on the leaves to control the diseases and insect pests, respectively (Chattopadhyay and Maity, 1967; Maity, 1989). However, all the agronomic requirements may vary from place-to-place, variety-to-variety, season-to-season and due to several other factors but the scientific data pertaining to these factors are scarce. Therefore, the relevant information particularly, on the edaphic, climatic and agronomic requirements of the crop for a particular production system is required to be worked out through in-depth research.

The crop is usually cultivated by the poor farmers generation after generation following the traditional methods. However, the scientific methods are also slowly penetrating the system by the virtue of the research work carried out under the "All India Coordinated Research Project On Betelvine" sponsored by the Indian Council of Agricultural Research, New Delhi. This would be evident from the Annual Reports, bulletins and research papers published by the scientists of the different centres of this project located in different places in the country (ICAR, 1997; ICAR, 2000; Maity, 1989). However, an effective extension work is required to be initiated to disseminate these research findings to the farmers so that they can maximize production, minimize cost of cultivation and also eliminate the risk of frequent devastation of the entire crop by the insect pests and diseases, particularly the latter ones.

The initial cost of cultivation of betel vine including construction of a Boroj may be about Rs 1- 2 lakh/ha at the minimum during the first year that may come down to about Rs $0.5-0.6$ lakh/ha in the subsequent years and a minimum net profit of Rs 0.5-1.0 lakh/ha/year or more (Rs $5.02 \mathrm{lakh} / \mathrm{ha} /$ year in one case as reported by ICAR, 2000) is not an unexpected value from a well-established farm though the figures may vary due to several factors like agro-climate, location of the farm, variety, demand and supply, season, variation in price of the leaves (which may vary significantly in the evening compared to morning), inflation etc. (Bhowmick, 1997; Guha and Jain, 1997; ICAR, 2000; Lahiri, 1991; Samanta, 1994; SDAMM, 1996). Such wild and unwarranted fluctuation in price of betel leaves may discourage cultivation of the crop and endanger the economic stability of the farmers. This may be safeguarded by evolving a wellregulated marketing system for which research work particularly, on the marketing systems and intelligence and allied aspects relevant to the crop are required to be initiated.

It is very interesting to note that in spite of such a high input requirement of the crop it's cultivation is quite affordable even to the small farmers as because it can be successfully cultivated in a very small area, as small as three 
decimals. Further, a small Boroj of even 10-15 decimals may provide considerable net profit for maintaining a small family of five members (Jana, 1995; SDAMM, 1996). Such a Boroj may be termed as a household bank since the leaves can be plucked and sold straight in the market as and when hard cash is required and this may continue for 10-30 years or more (Chattopadhyay, 1981; Jana, 1995). Further, since the leaves mature within 15-30 days (Jana, 1995) therefore, 1-4 harvestings are normally done every month (Guha and Jain, 1997). Thus, cultivation of betel vines provide a continuous source of income to the farming family unlike the major crops, which provide income only once in a year or so. That apart, most of the major crops require some sorts of post-harvest processing for making the produce marketable but the betel leaves do not require any such processing at all. Moreover, the leaves may also be retained on the vines for about six months without any visual signs and symptoms of deterioration (Bhowmick, 1997). This again provides an opportunity to escape the dull markets but the total production may get affected. Interestingly, the annual yield of a good crop is about 60-70 leaves/ plant and 6-7 million leaves/ ha. This may constitute a gross production of the leaves worth about Rs 9000 million every year in the country where the crop is grown on about 55,000 ha of land. On an average about $66 \%$ of such production is contributed by the state of West Bengal where it is cultivated on about 20,000 ha of land encompassing about 4-5 lakh Boroj employing about the same number of agricultural families (Guha and Jain, 1997; ICAR, 1997; Jana, 1996; Maity, 1996).

\section{MINIMIZING WASTAGE OF SURPLUS BETEL LEAVES}

The Betel leaf is a very perishable commodity and therefore, always subject to wastage by quick spoilage due to dehydration, fungal infection, dechlorophyllation etc. This may cause a postharvest loss ranging from $35 \%$ to $70 \%$ during transport and storage (Rao and Narasimham, 1977). Even if the most conservative estimate of $10 \%$ loss were considered that too would reveal a menacing loss of betel leaves worth about Rs 900 million every year to the country. Not only this, particularly in the rainy season a large portion of the leaves remain unsold or sold at a throw away price (Guha and Jain, 1997). So much is the wastage that the farmers try to reduce the production by curtailing the agricultural inputs during the glut season. Moreover, the surplus leaves are fed to the cattle and sometimes buried in the ground to avoid environmental pollution and health hazards caused by millions of decaying leaves, which is a total wastage at present. However, a strikingly contradictory situation may be observed during the peak demand period in the winter season when a single piece of good quality betel leaf (not a quid!) may cost as high as Rs 3.60/-(Guha, 1997).

In view of the alarming losses, attempts are being made to minimize the wastage by drying the leaves (Ramalakshmi et al., 2002), controlling senescence (Misra and Gaur, 1972), by chemical treatments, manipulation of storage temperature, adopting better packaging materials and methods (Guha, 2004; Rao and Narasimham, 1977) besides curing and bleaching of the leaves (Dastane, 1958; Sengupta, 1996). Such wastage may also be minimized by extracting essential oil from the stranded or unsold leaves be it fresh or stale or dechlorophylled or even partially decayed, by an apparatus called "Betel leaf oil extractor" designed and developed at IIT, Kharagpur. The essential oil extracted with this apparatus clearly revealed that the Mitha, Bangla and Sanchi varieties of betel leaves contained about $2.0 \%$, $1.7 \%$ and $0.8 \%$ essential oil respectively, on dry weight basis. This oil of Bangla variety was constituted by a mixture of about twenty-one different compounds of which eugenol was the chief ingredient constituting about $29.5 \%$ of the oil (Guha, 2003). Similarly, the essential oil and its constituents of most of the other varieties show a comparable trend but in some varieties terpenyl acetate is the chief constituent. However, these constituents may vary qualitatively and quantitatively as well due to several factors like variety, soil, climate and the agronomic practices followed to raise the crop etc. like any other essential oil yielding crops (Garg and Jain, 1996; Gunther, 1952; Kanungo, 1996; Ramalakshmi et al., 2002; Sankar et al., 1996; Sharma et al., 1981). In fact, these constituents are the sources of the medicinal, aromatic, stimulant, tonic and various other useful properties found in the leaves (Khanra, 1997). Such useful properties of the oil indicate a promising industrial future for it as a raw material for manufacturing skin emollients, tooth-pastes, tooth-powders, paan 
masala, perfumes, room fresheners, de-odorants, soaps, face creams, antiseptic creams and lotions, cold drinks, chocolates, incense sticks, appetizers, carminative mixtures, digestive agents, tonics, medicines etc (Guha, 2000). Therefore, research on "Development of products from betel leaves and essential oil" is required to be initiated urgently for exploiting the unique potentialities of the crop, which would also minimize the menacing wastage of the leaves.

\section{IMPACT OF BETEL LEAVES ON NATIONAL ECONOMY}

The vast economic potentiality of the crop can be adequately established by the fact that about 15-20 million people consume betel leaves in India on a regular basis (Jana, 1996) besides those in other countries of the world which may include over 2 billion consumers (Jeng et al., 2002). That apart a small Boroj of about three decimal area can generate employment opportunity for an agricultural worker throughout the year (Bhowmick, 1997) helping him to maintain his family. Further, as far as the national employment generation is concerned, it is estimated that about 20 million people derive their livelihood directly or indirectly, partly or fully from production, processing, handling, transportation and marketing of betel leaves in India, which includes about 5 million workers from West Bengal (Jana, 1995; Jana, 1996). In this way, the crop provides a National Income to the tune of Rs 6000- 7000 million every year and at the same time it also provides an income of Rs 800-1000 million to the state of West Bengal. In addition to this, the Railways earn about Rs 100 million every year from transporting betel leaves from West Bengal to different parts of India like Bilaspur, Cochin, Gondia, Gandhinagar, Hyderabad, Jabalpur, Jalgaon, Katni, Nagpur, New Delhi, Raipur, Srinagar, Trivendram etc (Jana, 1995; Samanta, 1994). The leaves are also in great demand in several other countries of the world where it is either not grown at all or the demand exceeds the local supply. Consequently, leaves worth about Rs 30-40 million are exported to the countries like Bahrain, Canada, Great Britain, Hong Kong, Italy, Kuwait, Nepal, Pakistan, Saudi Arab and many other European countries (Jana, 1996; Singh et al., 1990). This clearly indicates the foreign exchange earning potentiality of the crop, which is required to be strengthened in the interest of the nation. This may be achieved through proper research on export systems and intelligence besides modulation of the export-policy-decisions for boosting up export of betel leaves.

\section{MEDICINAL AND NUTRITIVE VALUE OF BETEL LEAF}

Betel leaf is traditionally known to be useful for the treatment of various diseases like bad breath, boils and abscesses, conjunctivitis, constipation, headache, hysteria, itches, mastitis, mastoiditis, leucorrhoea, otorrhoea, ringworm, swelling of gum, rheumatism, abrasion, cuts and injuries etc as folk medicine while the root is known for it's female contraceptive effects (Chopra et al., 1956; Khanra, 1997). Further, the essential oil contained in the leaves possesses antibacterial, antiprotozoan and antifungal properties. Therefore, the oil kills or inhibits growth of dreadful bacteria causing typhoid, cholera, tuberculosis etc that needs proper evaluation and exploitation (CSIR, 1969). Not only that, the betel leaves really do not have any match as a cheap, natural and easily available appetizer, digestive, mild stimulant, aphrodisiac and refreshing mastication. Chewing of betel leaves produce a sense of well-being, increased alertness, sweating, salivation, hot sensation and energetic feeling with exhilaration. It also increases the capacity to exercise physical and mental functions more efficiently for a longer duration but it may produce a kind of psychoactive effect causing a condition of mild addiction leading to habituation and withdrawal symptoms (Chu, 2001; Garg and Jain, 1996). Further, the leaves are very nutritive and contain substantial amount of vitamins and minerals (Table 1) and therefore, six leaves with a little bit of slaked lime is said to be comparable to about $300 \mathrm{ml}$ of cow milk particularly for the vitamin and mineral nutrition. The leaves also contain the enzymes like diastase and catalase besides a significant amount of all the essential amino acids except lysine, histidine and arginine, which are found only in traces (CSIR, 1969; Gopalan, 1984; Guha and Jain, 1997). However, relevant data from a complete biochemical analysis is not available from any single source. Consequently, the analytical values from two or more reports may reveal a very wide or even contradictory 
Table 1: Nutritional composition of fresh betel leaf

\begin{tabular}{llr}
\hline S. No. & Constituents & Approximate composition \\
\hline 1 & Water & $85-90 \%$ \\
2 & Protein & $3-3.5 \%$ \\
3 & Fat & $0.4-1.0 \%$ \\
4 & Minerals & $2.3-3.3 \%$ \\
5 & Fibre & $2.3 \%$ \\
6 & Chlorophyll & $0.01-0.25 \%$ \\
7 & Carbohydrate & $0.5-6.10 \%$ \\
8 & Nicotinic acid & $0.63-0.89 \mathrm{mg} / 100 \mathrm{~g}$ \\
9 & Vitamin C & $0.005-0.01 \%$ \\
10 & Vitamin A & $1.9-2.9 \mathrm{mg} / 100 \mathrm{~g}$ \\
11 & Thiamine & $10-70 \mu \mathrm{g} / 100 \mathrm{~g}$ \\
12 & Riboflavin & $1.9-30 \mu \mathrm{g} / 100 \mathrm{~g}$ \\
13 & Tannin & $0.1-1.3 \%$ \\
14 & Nitrogen & $2.0-7.0 \%$ \\
15 & Phosphorus & $0.05-0.6 \%$ \\
16 & Potassium & $1.1-4.6 \%$ \\
17 & Calcium & $0.2-0.5 \%$ \\
18 & Iron & $0.005-0.007 \%$ \\
19 & Iodine & $3.4 \mu \mathrm{g} / 100 \mathrm{~g}$ \\
20 & Essential Oil & $0.08-0.2 \%$ \\
21 & Energy & $44 \mathrm{kcal} / 100 \mathrm{~g}$ \\
\hline
\end{tabular}

trend. Therefore, research work in this direction becomes inevitable.

\section{THE CANCER CONTROVERSY ON BETEL LEAVES}

In spite of the nutritive, stimulating and refreshing properties, excessive consumption of betel leaves like any other edible items may also prove to be harmful particularly to the teeth. Such harmful effects are exerted by the additional ingredients consumed along with the leaves for making the quid more palatable and attractive. These include in particular, the tobacco or allied products, which really call for a word of caution. This is because the tobacco based quids may cause dental caries, alveolaris, oral sepsis, palpitation, neurosis and even oral cancer (CSIR, 1969) but the non-tobacco based quids are not known for sure to cause any such calamity particularly at a non-addictive level of consumption. However, there is no denial of the fact that the leaves may contain a good amount $(15 \mathrm{mg} / \mathrm{g})$ of Safrole (Chen et al., 1999; Sharma et al., 1996), a carcinogen, but it is quickly metabolized in human body into dihydroxychavicol and eugenol, which are excreted along with urine (Chang et al., 2002a). The betel leaves are also reported to possess antioxidant activity besides antimutagenic and anticarcinogenic properties particularly against the tobacco carcinogens
(Chang et al., 2002b; Padma et al., 1989a, Padma et al., 1989b; Wu et al., 2004) due to the presence of ingredients like hydroxychavicol (Amonkar et al., 1989) and chlorogenic acid (TNN, 2004) in it. The latter compound is also reported to kill the cancerous cells without affecting the normal cells unlike the common cancer drugs and relevant therapeutic means. Therefore, possibility of manufacturing of a new blood cancer drug from it cannot be ruled out. In fact, some scientists from the Indian Institute of Chemical Biology, Kolkata have applied for a patent for the drug. If successful, the drug would also fetch substantial amount of foreign exchange to the country and highlight the significance of betel leaf to a further extent (TNN, 2004). Contrary to the above, there are a few reports, which indicate that chewing betel leaves may independently produce carcinogenic effects (Chen et al., 1999; Merchant et al., 2000). However, the evidences are inadequate and do not match with the traditional history of betel leaf chewing in India. Interestingly, it is also claimed that the inflorescence of betel vine contains carcinogens whereas the leaves possess anticarcinogenic agents. This practically indicates that parts of the same plant contain carcinogenic and anticarcinogenic substances ( $\mathrm{Wu}$ et al., 2004). In view of the above controversial claims, it becomes imperative to carry out conclusive biochemical and genetic investigations together with clinical trials and demographic studies before imposing such a horrifying malignant property on betel leaf.

\section{CONCLUSION}

The economic aspects of the crop as discussed above evidently prove that betel leaf is one of the most promising commercial crops capable of attracting substantial amount of foreign exchange to the country. This adequately justifies its nomenclature as the "Green Gold of India". It is further envisaged that if merely transportation and marketing facilities including the export channels were developed adequately then the revenue generated by this leafy crop would easily exceed that generated by any major crop of the country even with the present level of traditional agronomic practices. In fact, the revenue generated by the crop may be further magnified by many folds if the agronomic practices are scientifically explored well. In spite of such 
tremendous economic potentiality of the crop, it remains neglected particularly by the scientists, technologists, administrators and the policy makers as well. Consequently, statistical data of betel leaf is still scattered and messy while its agronomy remains to be a matter of personal experience gained through traditional farming practiced generation after generation. Not only those, the post-harvest handling, processing and storage of the crop also have not been scientifically explored well. Consequently, betel leaves worth millions of rupees are sold at a throw away price and some times remain even completely unsold and get wasted. This again indicates that the present level of revenue generated by the crop may be increased by many folds if appropriate post-harvest technologies are made available to the betel leaf growers and traders. Therefore, a well-coordinated effort by the farmers, traders, scientists, technologists, extension workers, physicians, administrators and policy makers is required to be initiated to boost up the national economy as well as the national employment generation through proper exploitation of this green gold.

\section{ACKNOWLEDGEMENTS}

The author is grateful to the ICAR, New Delhi and IIT, Kharagpur for providing necessary funds and facilities respectively, for the work. He is also grateful to Dr. S. L. Srivastava (Sr. Scientist), Mr. A. Mahapatra and Mr. R. C. Pradhan (Research workers), IIT, Kharagpur for checking the manuscript.

\section{REFERENCES}

Amonkar, A.J., Padma, P.R. and Bhide, S.V.: Protective effect of hydroxychavicol, a phenolic component of betel leaf, against the tobacco-specific carcinogens. Mutat. Res., 210(2): 249-253(1989).

Bhowmick, S.: Paan: Anadrita Laxmi (In Bengali). "Betel leaf: The Neglected Goddess of Wealth." Moyna Prakashani, Calcutta (1997).

Chang, M. J.W., Ko, C.Y., Lin, R.F. and Hsiesh, L.L.: Biological monitoring of environment exposure to Safrole and the Taiwanese betel quid chewing. Archives of Environmental Contamination and Toxicology, 43(4): 432-437 (2002a).

Chang, M.C., Uang, B.J., Wu, H.L., Lee, J. J., Hahn, L. J. and Jeng, J.H.: Inducing the cell cycle arrest and apoptosis of oral KB carcinoma cells by hydroxychavicol: Roles of glutathione and reactive oxygen species. British J. Pharm., 135: 619-630 (2002b).

Chattopadhyay, T.K.: Betelvine cultivation in West Bengal, pp. 121-124, In: Proc. of Group Discussion On Improvement of Betelvine Cultivation. S.D. Khanduja and V.R. Balasubrahmanyam (Eds.). National Botanical Research Institute, Lucknow, India (1981).

Chattopadhyay, S. B. and Maity, S.: Diseases of Betelvine and Spices. ICAR, New Delhi (1967).

Chen, C., Chi, C., Chang, K. and Liu, T.: Safrole-like DNA adducts in oral tissue from oral cancer patients with a betel quid chewing history. Carcinogenesis, 20(12): 2331-2334 (1999).

Chopra, R.N., Nayar, S.L. and Chopra, I.C.: Glossary of Indian Medicinal Plants, pp.194. CSIR, New Delhi (1956).

Chu, N. S.: Effects of betel chewing on the central and autonomic nervous systems. J. Biomedical Sci., 8(3): 229236 (2001).

CSIR (Council of Scientific and Industrial Research, New Delhi): The Wealth of India, 8: 84-94. CSIR, New Delhi (1969).

Dastane, N.G., Patil, R.G. and Chaugule, B.A.: This business of bleaching betel leaves, Indian Farming, 7(10): 10-12 (1958).

Garg, S.C. and Jain, R.: Chavicol rich essential oil of Piper betle L., Cutivar Sagar Bangla. Euro Cosmetics, 5: 2728 (1996).

Gopalan, C., Ramasastri, B.V. and Balasubramanian, S.C.: Nutritive Value of Indian Foods, pp. 108. National Institute of Nutrition (ICMR), Hyderabad, India (1984).

Guha, P.: "Paan Theke Kutir Silpa Sambhabana" (In Bengali). "Exploring Betel Leaves for Cottage Industry", pp. 1519, In: Krishi, Khadya-O- Gramin Bikash Mela -A Booklet published by the Agricultural and Food Engineering Department, IIT, Kharagpur, India (1997).

Guha, P.: Commercial exploitation of oil from betel leaves, pp. 56-57, In: Proc. Sixth Regional Workshop on Oil Seeds and Oils. IIT, Kharagpur (Ed.). Agricultural and Food Engineering Department, IIT, Kharagpur, India (2000).

Guha, P.: Extraction of essential oil from betel leaves grown in and around Midnapur District, pp.15-23, In: Annual Report of All India Coordinated Research Project on Post Harvest Technology (ICAR). IIT, Kharagpur (Ed.). Food and Agricultural Engineering Department, IIT, Kharagpur, India (2003).

Guha, P.: Development of technology for enhancing shelf life of betel leaves (Piper betle L.), pp. 39-56, In: Annual Report of All India Coordinated Research Project on Post Harvest Technology (ICAR). IIT, Kharagpur (Ed.). Food and Agricultural Engineering Department, IIT, Kharagpur, India (2004)

Guha, P. and Jain, R.K.: Status Report On Production, Processing and Marketing of Betel Leaf(Piper betle L.). Agricultural and Food Engineering Department, IIT, Kharagpur, India (1997).

Gunther, E.: The Essential Oils, 5: 160-161. D. Van Nostrand \& Co, Inc. New York (1952).

ICAR (Indian Council of Agricultural Research, New Delhi): Annual Report of All India Coordinated Research Project on Betelvine (ICAR), Indian Institute of Horticultural Research, Hessarghatta, Bangalore, India (1997).

ICAR (Indian Council of Agricultural Research, New Delhi): Annual Report of All India Coordinated Research Project on Betelvine (ICAR). National Research Centre For Medicinal And Aromatic Plants, Boriavi, Gujarat, India (2000).

Jana, B.L.: Gram Banglar Arthakari Phasal-Paan (In 
Bengali). "Betel Leaf: ACash Crop of Villages of Bengal". Asaboni, Flat 203, 184, B. B. Chatterji Road, Calcutta (1995).

Jana, B.L.: Improved technology for betel leaf cultivation. A paper presented in the "Seminar-cum-Workshop on Betel leaf Marketing", held at State cashew nut farm, Directorate of Agricultural Marketing, Digha, Midnapur (W. B.), India, June 5-6, 1996 (1996).

Jana, B.L.: Arthakari phasal paan-o- paan chas prajukti (In Bengali). "Betel leaf: A cash crop and its production technology." Nabanna Bharati, 30(9): 450-455 (1998).

Jeng, J. H., Chen, S.Y., Liar, C.H., Tung, Y.Y., Lin, B.R., Hahn, L.J. and Chang, M.C.: Modulation of platelet aggregation by areca nut and betel leaf ingredients: Roles of relative oxygen species and cyclooxygenase. Free Radical Biology and Medicine, 32 (9): 860-871 (2002).

Khanra, S.: Paan Vittik Silpakendra (In Bengali). "Betel Leaf Based Industry". Nabanna Bharati, 30(2): 169 (1997).

Kanungo, S.P.: Package of practices and agronomic manipulations in Cymbopogan species, pp.13-16, In: CSIR Technology Utilization for Rural Development (Aromatic and Spice Plants). RRL, Bhubaneswar (Ed.) (1996).

Khoshoo, T.N.: Welcome address, pp. xvii-xx, In: Proc. of Group Discussion on Improvement of Betelvine Cultivation. S.D. Khanduja and V.R. Balasubrahmanyam (Eds.). National Botanical Research Institute, Lucknow, India (1981).

Lahiri, D.: A Study of Betel Leaf Marketing in Midnapur District, West Bengal. A Report on an Ad-hoc research project (ICAR), Rural Development Centre, IIT, Kharagpur (1991).

Maity, R.: Paaner Arthaniti, Banijjya-o -paan chasider samasya (In Bengali). "Economics, Commerce and Problems of Betelvine Cultivators". A paper presented in the "Seminar-cum-Workshop on Betel leaf Marketing", held at State cashew nut farm, Directorate of Agricultural Marketing, Digha, Midnapur (W. B.), India, June 5-6, 1996 (1996).

Maity, S.: Extension Bulletin: The Betelvine. All India Coordinated Research Project on Betelvine, Indian Institute of Horticultural Research, Hessarghatta, Bangalore, India (1989).

Mehrotra, R.S.: Fungal diseases of betelvine and their control, pp. 3-12, In: Proc. of Group Discussion on Improvement of Betelvine Cultivation. S.D. Khanduja and V.R. Balasubrahmanyam (Eds.). National Botanical Research Institute, Lucknow, India (1981).

Merchant, A., Husain, S.S.M., Hosain, M., Fikree, F.F., Pitifat, W., Siddiqui, A.R., Hyder, S.J., Halder, S.M., Ikran, M., Chuang, S.K. and Saeed, S.A.: Paan without tobacco: An independent risk factor for oral cancer. Int. J. of Cancer, 86(1): 128-131 (2000)

Mishra, D., Mishra, S.K., Acharya, A. and Das. J.N.: Annual Report of All India Coordinated Research Project on Betelvine. Department of Plant Pathology, College of Agriculture, Orissa University of Agriculture and
Technology, Bhubaneswar, India (1997).

Mishra, S.D. and Gaur, B.K.: Control of senescence in betel leaves by depetiolation. Exptl., Gerant., (7): 31-35 (1972).

Padma, P.R., Amonkar, A.J. and Bhide, S.V.: Antimutagenic effects of betel leaf extract against the mutagenicity of two tobacco-specific N-nitrosamines. Mutagenesis, 4: 154$156(1989 a)$

Padma, P.R., Lalitha, V.S., Amonkar, A.J. and Bhide, S.V.: Anticarcinogenic effect of betel leaf extract against tobacco carcinogens. Cancer Lett., 45 (3): 195-202 (1989b).

Ramalakshmi, K., Sulochanamma, G., Rao, L. J. M., Borse, B.B. and Raghavan, B.: Impact of Drying on quality of betel leaf (Piper betle L.). J. Food Sci. Technol., 39 (6): 619-622 (2002).

Rao, V. M. and Narasimham, B.: Prolonging storage life of betel leaves, Indian J. Hort., 34 (2): 175-182 (1977).

Samanta, C.: Paan chaser samasyabali-o-samadhan: Ekti samikkha (In Bengali): "A Report on the Problems and Solutions of Betel Vine Cultivation". A booklet published by Mr. H. R. Adhikari, C-2/16, Karunamoyee, Salt Lake City, Kolkata-64 (WB), India (1994).

Sankar, C. R., Sridevi, D. and Babu, M. K.: Studies on essential oil and oil constituents of betel vine cultivars. The Andhra Agric. J., 43 (1): 24-26 (1996).

SDAMM (Superintendent, Directorate of Agricultural Marketing, Midnapur): Paaner Kotipoy Tathya (In Bengali). "Some aspects of betel leaf."A paper presented in the "Seminar-cum-Workshop on Betel leaf Marketing", held at the state cashew nut farm, Directorate of Agricultural Marketing, Digha, Midnapur (W. B.), India, June 5-6, 1996 (1996).

Sengupta, K.: Pan Patar Sangrakkhan (In Bengali). "Preservation of Betel Leaves." Nabanna Bharati, 28(12): 580-582 (1996)

Sharma, M.L., Rawat, A.K.S., Balasubrahmanyan, V.R. and Singh, A.: Essential oil of betel leaf (Piper betle, L.) cv. Kapoori, pp. 161-164, In: Proc. of Group Discussion On Improvement of Betelvine Cultivation. S.D. Khanduja and V.R. Balasubrahmanyam (Eds.). National Botanical Research Institute, Lucknow, India (1981).

Sharma, M.L., Rawat, A.K.S., Khanna, R.K., Chowdhury, A.R. and Raina, R.M.: Flavour characteristics of betel leaves. Euro cosmetics, 5: 22-24 (1996).

Singh, K.K., Balasubrahmanyam, V.R. and Kochhar, V.K.: Effect of different packing methods, temperature conditions, treatment with chemicals on the senescence and storage behaviour of betel (Piper betle L.) leaves. $J$. Plant. Crops, 18 (1): 23 - 28 (1990).

TNN (Times News Network): Paan- Indian cure for leukemia. The times of India, Kolkata (31.7.2004). Retrieved on 4.11.2004 from <http: //www.hvk.org/articles/0804/ 22.html.

Wu, M.T., Wu, D.C., Hsu, H.K., Kao, E.L. and Lee, J.M.: Constituents of areca chewing related to esophageal cancer risk in Taiwanese men. Diseases of the Esophagus, 17 (3): 257-259 (2004). 